\title{
THE EARLY CAROLINGIAN SPUR FROM SMOLENICE, FOUND IN $1934^{1}$
}

\author{
Zbigniew Robak
}

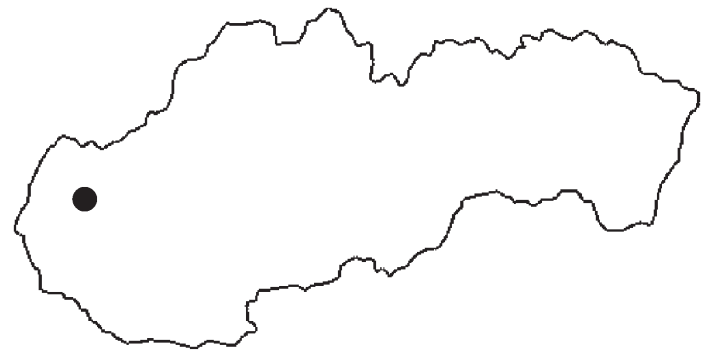

DOI: https://doi.org/10.31577/szausav.2019.66.8

Keywords: Early Middle Ages, Middle Danube Region, Smolenice, Carolingian weapon, spurs

The paper presents the analysis of a loop spur found during A. Loubal's research in 1934 on Smolenice-Molpír hillfort. The item is known in the literature for a long time. However, the method of its publication prevented proper scientific evaluation of the artefact. The schematic drawing documentation prompted archaeologists to consider the spur an imitation. A more detailed analysis of the find shows that it is an uncommon item in Western Slovakia, namely an Early Carolingian original dated back to the turn of the $8^{\text {th }}$ and $9^{\text {th }}$ century or the beginning of the $9^{\text {th }}$ century.

\section{INTRODUCTION}

A. Loubal organised excavations in the area of the Smolenice-Molpír hillfort in 1934. The Early Carolingian spur he found then is known in the literature for a long time. However, the original publication prevented proper scientific analysis of the artefact. The schematic drawing documentation (Ruttkay 1975, fig. 22: 9) induced researchers to consider it an imitation, while in fact, it is a relatively rare - at least in Western Slovakia - Western European product typical for the turn of the $8^{\text {th }}$ and $9^{\text {th }}$ century (Fig. 1).

The earliest information about the early medieval finds from Smolenice come from the end of the $19^{\text {th }}$ century (Nagy 1896, 359; Sándorfy 1890, pl. II: 2). It was the time when the Molpír hillfort was identified. Although nearly immediately amateur archaeologists started their investigations on the site and its vicinity, we have almost no information about the finds. The same applies to the excavations organised in the 1930s (Romsauer 2011, 39, 40). Later, the Smolenice-Molpír hillfort was regularly studied in the 1960s (Dušek 1965; Dušek/Dušek 1984; 1995). The researchers focused on the Hallstatt phase, clearly underestimating La-Tène and early medieval artefacts. The significance of the site was confirmed by a series of finds obtained by private collectors that - ultimately - were deposited in the Slovak National Museum - Archaeological Museum in Bratislava (Šimčík 2007; Turčan 1994; 1995; 2011). Even today, the hillfort, as well as its area, is constantly devastated and plundered by amateur treasure hunters.

Apart from the spur, we know also another loop spur from Smolenice-Molpír (Fig. 2), a fragment of a buckle spur yoke (Fig. 3: 3), three hooked spurs (one decorated), fragments of Carolingian sword pommels (Fig. 3: 1, 2), a collection of Late Avar bronzes and other pieces of early medieval weaponry (Dušek/Dušek 1984, pl. 100: 2; 1995, pl. 128: 6; 18; Turčan 1994; 1995). Allegedly, on the nearby hill, Záruby, a type $\mathrm{H}$ Carolingian sword dated back to the first half of the $9^{\text {th }}$ century was found (Fig. 4; Turčan 2011). On another hill, Dolné Orešany-Rekomberek, one of the largest deposits of early medieval, mainly Late Avar, decorations (Pieta/Ruttkay 2017), including one Carolingian find decorated with the plant ornamentation and dated back to the beginning of the $9^{\text {th }}$ century (Robak 2017b). All these can confirm

1 This study was conducted with the support of the VEGA project 2/0001/18 and as a sustainability impact indicator of the project ITMS: 26220120059. I thank Dr. V. Turčan from SNM Archaeological Museum in Bratislava for his help in finding the spur and making it available for my research. I thank Dr. M. Adamus for the adjustments and English translation of the paper. 


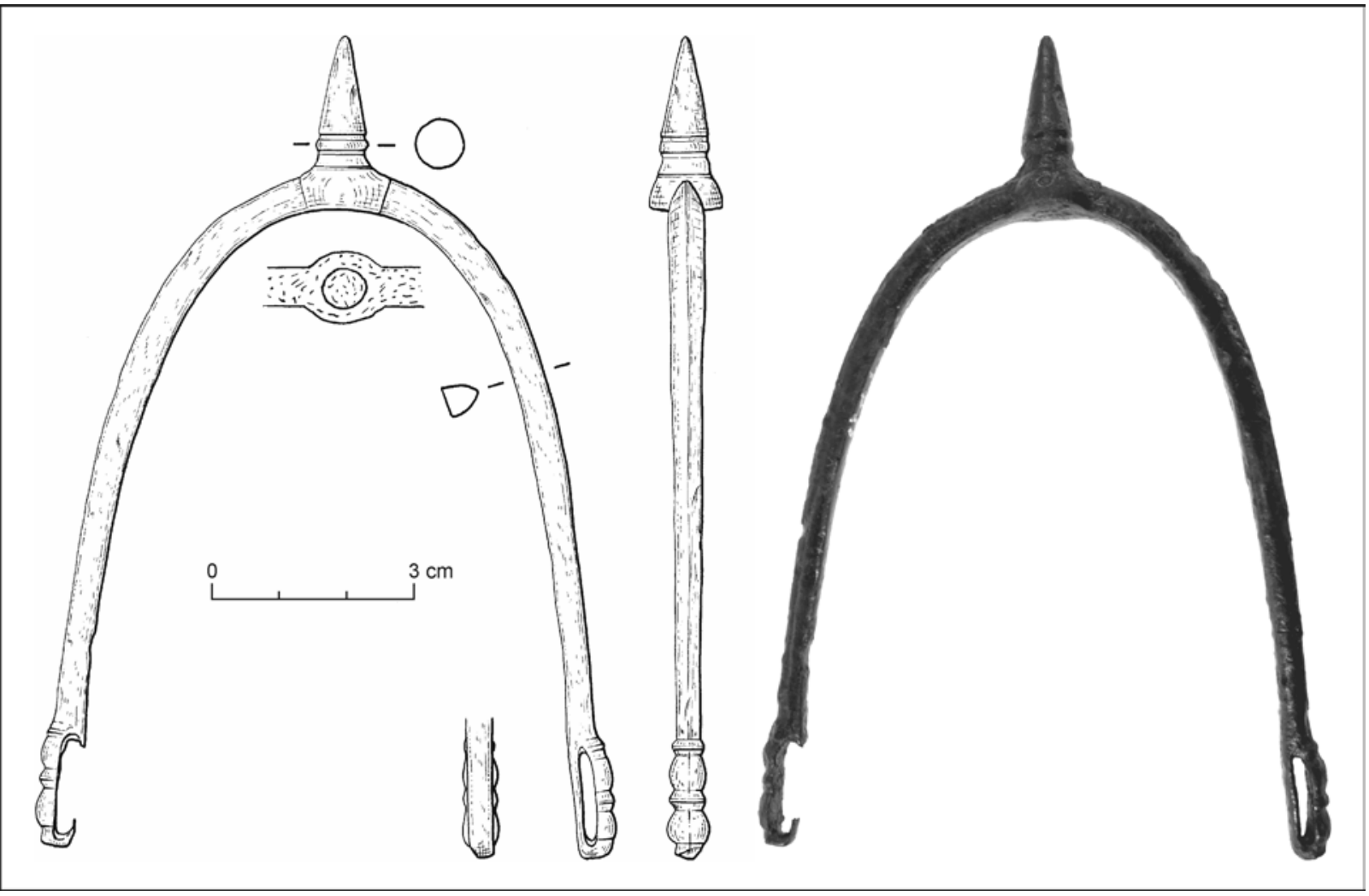

Fig. 1. Smolenice-Molpír. The loop spur. Iron. Drawn N. Vaššová, photo Z. Robak.

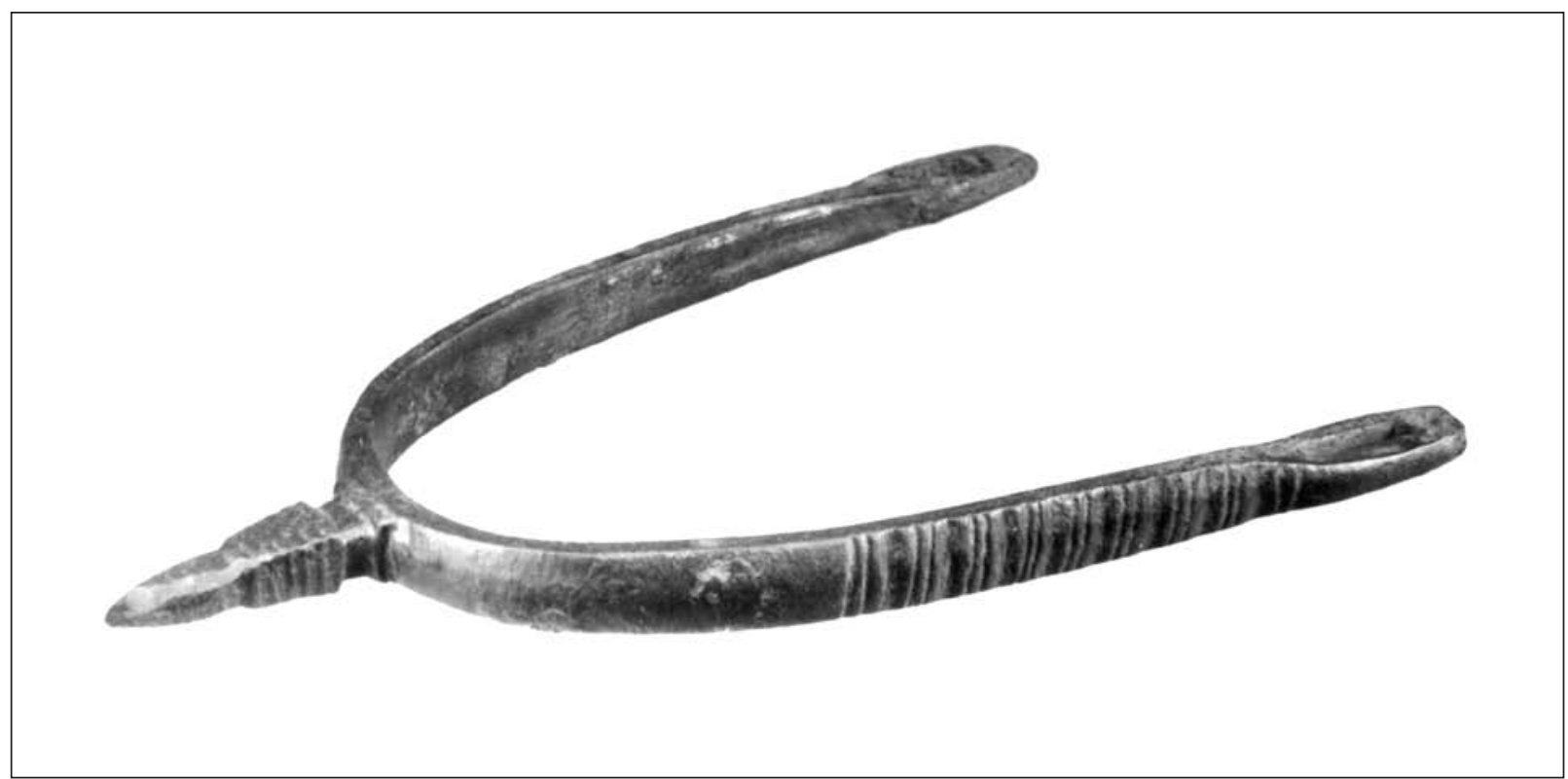

Fig. 2. Smolenice-Molpír. The loop spur. Iron (private collection). Photo SNM - Archaeological Museum. No scale. 


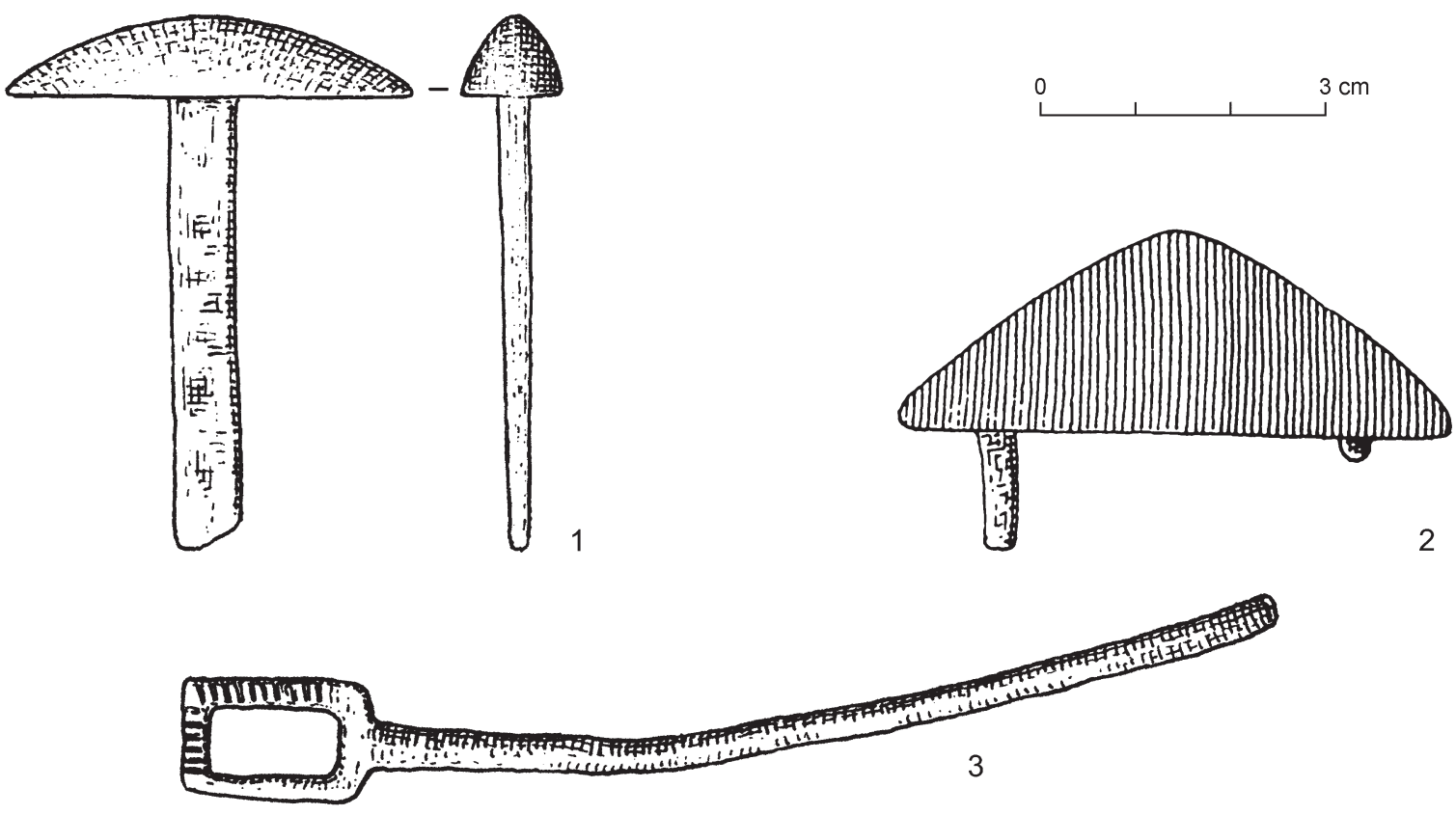

Fig. 3. Smolenice-Molpír. 1, 2 - Carolingian sword's pommels; 3 - fragment of a buckle-spur. Iron (Dušek/Dušek 1984; 1995).

that at the turn of the $8^{\text {th }}$ and $9^{\text {th }}$ century, a local power centre emerged in the area of Smolenice. The centre, however, could not compete with those located in the Morava, Wah and Nitra valleys. Despite this, the site in Smolenice retained its function even later, in the Great Moravian times - at least in the $9^{\text {th }}$ century - when it became an element in the chain of hillforts protecting routes passing through the Little Carpathians and linking the Morava valley with the Wah valley (Turčan 1994, 80, 81). Some of the troop members stationed there could be later buried on a cemetery located in today village of Smolenice (Dušek 1979; Farkaš 1995). Most likely, the village itself was a settlement background of the hillfort.

\section{THE SPUR}

The spur from the Smolenice-Molpír hillfort is known for nearly 100 years. It was found during excavations organised by A. Loubal in 1934, close to the "second rampart" - according to the measurements of the hillfort made by Š. Janšák in 1930. It was first mentioned by the finder himself in 1935 (Loubal 1935) and then by J. Eisner $(1935,78)$. Both correctly described it as "Carolingian". Unfortunately, the documentation of the A. Loubal's research has not survived and thus it is impossible to draw detailed conclusions about context of the find. The information that the spur was found "between the Hallstatt and Slavic pottery from $9^{\text {th }}-10^{\text {th }}$ century" (Fig. 5; Loubal 1935) suggests that it was found rather in a cultural layer than in a feature backfill. The drawing of the spur was published in the museum catalogue in 1975 with a brief comment that the item is missing (Ruttkay 1975, 177, 178, fig. 22: 9). Fortunately, it was found later under another register number. The drawing, however, does not do justice to the item. Based on the publication from 1975, we could consider the spur a simple early medieval loop or quasi-loop spur. This could be a reason why the spur did not attract more interest of the archaeologists satisfied with this schematic publication. ${ }^{2}$

2 I made this mistake myself when I used a drawing of the spur in the "Bojná 2" and considered it an analogy for the spur from Bojná-Žihlavník (Robak 2017a, 60, 61). Fortunately, the mistake does not undermine the validity of analysis presented there. Once again, however, it shows that is better to be safe than sorry and to control the sources carefully. Although T. Kind (2007, 587, no. 30) mentions the spur among mit gebuckelten Ösen und/oder Tassilokelchstilornament spurs, he provides no drawing and adds a comment "unpublished" which may suggest that it is another, yet unknown item. 
The spur is $12.2 \mathrm{~cm}$ long. One of the loops is damaged and the yoke above it is slightly bent. Otherwise, the spur is in good condition. The spur was made of two separate parts - the yoke and the prick placed in an opening $0.6 \mathrm{~cm}$ in diameter. The yoke span is $8.7 \mathrm{~cm}$ and its internal height is $9.5 \mathrm{~cm}$. It was made from a rod triangle in the intersection. The yoke tips ended with loops. Dimensions of the loops allowed wrapping straps not wider than $1.2 \mathrm{~cm}$ and not thicker than $0.2 \mathrm{~cm}$. Loops were formed by bending the rod inwards and the joint can be seen only after meticulous examination. External edges of the loops are decorated with two knee-like thickenings. The prick is $2 \mathrm{~cm}$ long and together with the part hidden in the yoke, it is $2.7 \mathrm{~cm}$ long. At the base, the prick is profiled.

\section{TYPOLOGY AND CHRONOLOGY}

The spur from Smolenice is a typical example of early medieval loop spurs (Schlaufensporen) that is spurs with yoke tips formed in rectangular, oval or - less frequently - triangle frames. Similar specimens are known mainly from northern parts of Germany (Goßler/Posluschny 1998; Kind 2007, 586, 587) and are known from Dalmatia along with other imports from Western Europe (Milošević 2006). Loop spurs are common in Western European Late Merovingian cemeteries, in assemblages dated back to the second half of the $8^{\text {th }}$ century (Kleemann 2002, 126; Stein 1967). Usually, such spurs were accompanied by narrow strap-ends with faceted edges (type B1) and later with fittings with an inset (type A1) or the so-called leaf-shaped fittings (type A2, in the older literature sometimes referred to as bird-shaped; Robak 2013, pl. 1). J. Kleemann $(2002,126)$ dates the horizon of graves containing such spurs and fittings with an inset back to the III and IV phase of the so-called FrisianSaxon northwestern circle. The youngest assemblages containing such spurs - Schortens, grave 217a and Borne - could be dated based on the presence of Charlemagne denarius back to the period after 771 (around 790/794). This date is consistent with Kleemann's IV phase ranging from about 770 to 800/810 (Kleemann 2002, fig. 87; Rötting 1999, 244; Schulze-Dörrlamm 2010, 346). At the turn of the $8^{\text {th }}$ and $9^{\text {th }}$ century, in Western Europe loop spurs were replaced by plate spurs. Typologically, the process is well reflected by spurs from grave 1 from Oldendorf with one yoke arm ended with a loop and another with a plate (Laux 1983, fig. 1).

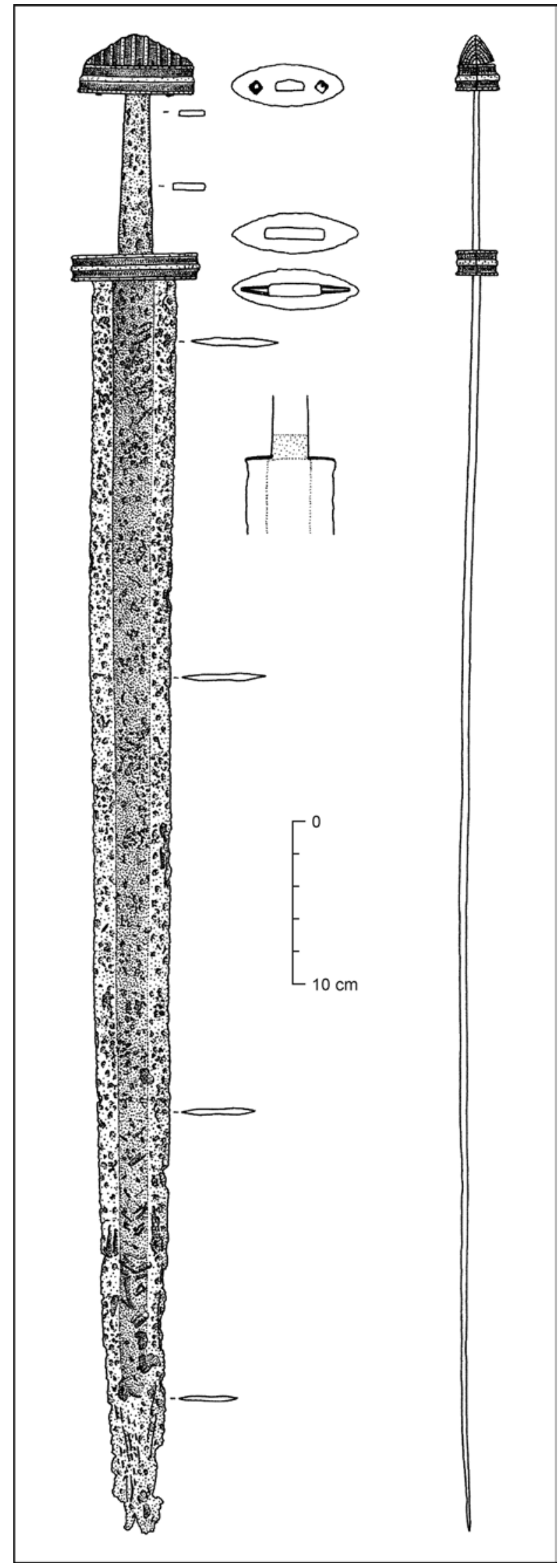

Fig. 4. Smolenice-Záruby. Carolingian sword of the H-type. Iron (Turčan 2011). 
Slovenský denik

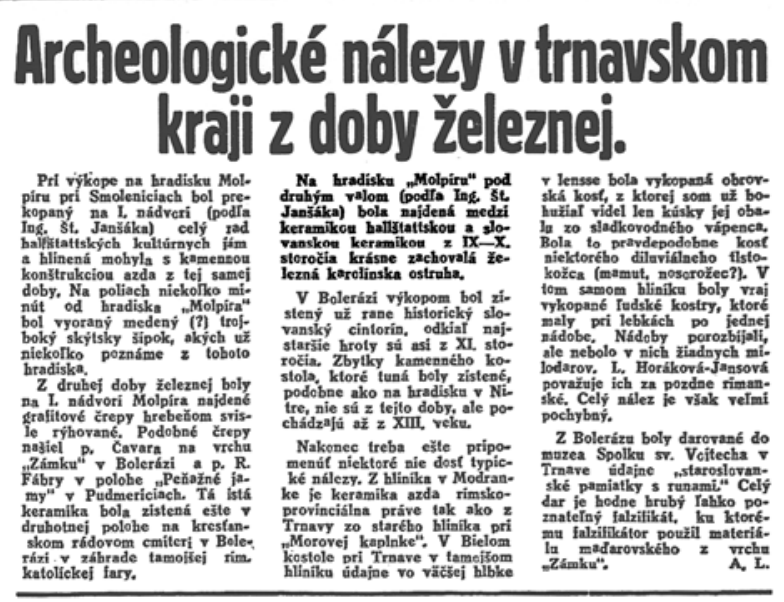

Fig. 5. News from the Slovenský denník of July $5^{\text {th }} 1935$.

The decorating pattern - namely double thickening at the edges - is typical mainly for younger examples of loop spurs. The older items were usually ribbed. Double thickening can be observed also on loop spurs made of bronze and richly decorated in the so-called Tassilo Chalice Style. Generally, the pattern can be considered one of the characteristic features of the style. Except for the spur from Sursee, nearly all bronze loop spurs known in the literature decorated in the Tassilo Chalice Style or some related style used in the Early Carolingian period - Barleben, Dorestad, Hambacher Forst, Haithabu, Mainz, Pfahlheim and Welbsleben - were also decorated with thickening (Sander 2007, 69; Wamers 1994, 32).

All these allow us to synchronise the bronze items with iron specimens with simplified decorations such as thickenings and notches. The item from Smolenice can be, thus, dated back to the turn of the $8^{\text {th }}$ and $9^{\text {th }}$ century or the very beginning of the $9^{\text {th }}$ century. Its close resemblance to the items from Sundremdy (Deubler 1966, pl. 39), Osnabrück (Schlüter/Zehm 1992, fig. 31: 4) and Gornji Vrbljani (Milošević 2006, fig. 6: 1) suggests that the spur is an import from Western Europe.

\section{ARCHAEOLOGICAL AND HISTORIC CONTEXT}

The areas located to the east of the Frankish state, that is the Slavic lands, loop spurs are rare, at least comparing to other types of Carolingian spurs. Among these, specimens that based on the stylistics could be considered Western European imports are exceptional (Kind 2007, 587). In some cases, it is impossible to tell whether the items were imported or produced locally and decorated with a simplified ornament (Profantová 1994, 71). Generally, so far, there is no proof that such spurs were produced locally in larger quantities. The lower popularity of loop spurs in the Slavic territories can be explained with relatively low intensity of Western European cultural influences in the period of the greatest popularity of such items ( $8^{\text {th }}$ century) as well as in the entire Merovingian period ${ }^{3}$. The very first clear wave of Western European imports to the Slavic Central and Southern Europe - the so-called Early Carolingian wave, ca. 790-820 - started when loop spurs lost their popularity in Western Europe. Consequently, such spurs are uncommon in the archaeological material linked with this wave (Robak 2017-2018). On the contrary, the material abounds with more technologically advanced buckle spurs or plate spurs with rivets placed at the sides.

It seems that loop spurs - although not completely unknown to the Slavs - were not attractive enough to replace hooked spurs, which were ultimately substituted by various types of plate spurs. However, Western European loop spurs influenced both the production and the design of Slavic hook and quasi-loop spurs (with tips bent and touching the yoke) (Wachowski 1991, 89, 90). In the former case, the influence was stylistic while in the latter typological. Similar notches and thickenings decorated iron and particularly bronze spurs with short yokes attributed to variation $\mathrm{A}$ and $\mathrm{B}-\mathrm{C}$ reflecting the fashion prevalent in the $8^{\text {th }}$ century and at the beginning of the $9^{\text {th }}$ century in Western Europe. Relatively rare quasi-loop spurs with long yokes typologically imitated loop spurs. Although Carolingian loop spurs disappear in the first half of the $9^{\text {th }}$ century, the Slavs could produce quasi-loop

\footnotetext{
3 To explain this lower intensity of contacts as well as later intensification we should look at the political history of Europe in the $7^{\text {th }}$ and $8^{\text {th }}$ century, however the issue is so complex that it cannot be thoroughly discussed in this brief paper. The only exception in terms of the number of Merovingian imports is North-Western Slavic territories where numerous hooked spurs can be actual imports from the West. Probably the differences were related to the geographical location of the lands on the Baltic Sea coast - at the borderland between many cultures (Brather 1996; Janowski 2017). However, when comparing this with the Carolingian period, the general picture remains intact.
} 
spurs with long yokes until the end of the $9^{\text {th }}$ century and hooked spurs even longer (Profantová 1994, 71). Nearly all known such spurs, however, are simplified and aesthetically unappealing. Therefore, we can assume that in the $9^{\text {th }}$ century, hooked and quasi-loop spurs were acceptable substitutes for those who could not afford, due to financial or technological issues, more luxurious items such as plate spurs.

Only until recently, single examples of Carolingian loop spurs in the Slavic lands were known only from Lower Silesia (Żak 1959, fig. 14) ${ }^{4}$ and Dalmatia (Milošević 2006). In the former case, it was an isolated, single find of a Carolingian type item found outside context and, thus, difficult to interpret (see Robak $2018 a, 76,77)$. In the latter, the presence of loop spurs in today Croatia should be linked with the wave of early Carolingian weaponry to the area. This was the earliest wave of Carolingian imports of the Slavic territories (Robak 2017-2018, 331, fig. 2), most distinct in today Croatia and Slovenia, often referred to as the early phase of the Biskupija-Crkvina horizon. The horizon reflects the actual presence of Carolingian troops in this area due to the campaign against the Avars (791-803) and later operations aiming at retaining the control over these lands (Dzino 2010, 182-187; Štih 2010, 132, 133). Chronological frameworks of the phase could be narrowed to the period between 790 and 820 . The items characteristic for the phase include mainly spurs with side rivets and buckle spurs as well as items (strap fittings, buckles, slides) decorated with typical thickenings and Tassilo Chalice Style or related ornaments. Some (possibly even most) of these types of items are local products quite faithfully imitating the Western European stylistics (Jurčević 2011). A relatively small number of loop spurs in the mass of artefacts attributed to the first phase is probably related to the decreasing popularity of such spurs at the time. Consequently, we can safely assume that in Western Europe such spurs were already obsolete. Those that reached Dalmatia or Slovenia most likely travelled there "on legs" of their direct users. However, they never gained sufficient popularity to be locally produced, possibly also due to the advent of a new, technologically more advanced type of plate spurs.

The intense archaeological research as well as activities of the so-called amateur explorers - often using metal detectors - led to a significant increase of metal finds in the Czech Republic and Slovakia, including also Early Carolingian finds. Interestingly, Early Carolingian and generally Carolingian finds are found mainly in the Bohemian Basin (Profantová 2016b; 2017), while in Moravia and Western Slovakia there are only three new finds in recent ten years (Robak 2015, fig. 2: 9, 13; 2018b). The concentration of Early Carolingian finds from the Bohemian Basin is consistent with the observation made by E. Wamers $(1993,41 ; 1999,436)$ that there is a correlation between concentrations of Early Carolingian types of finds (particularly decorated in the Tassilo Chalice Style) and the longer physical presence of Carolingian nobility and army confirmed by historic sources. The research on the occurrence of various Carolingian finds on eastern peripheries of the Carolingian state confirms this correlation also for Early Carolingian styles other than the Tassilo Chalice Style (Robak 2013; 2015; 2017-2018; 2018b). Some Frankish troops were already, briefly, present in the Bohemian Basin during the campaign against the Avars in 791. In that campaign, the Czechs most likely were the Frankish allies. Then, in 805-806 the Franks organised two campaigns against the Czechs themselves (Tř ̌štík 2001, 57-63, 71-85). The Early Carolingian weaponry, so far there are no other kinds of finds, could be traces of these operations. Scarce finds from Moravia and Slovakia reflect the fact that at the turn of the $8^{\text {th }}$ and $9^{\text {th }}$ century, these areas did not interest the Franks, there were no Carolingian troops there and any official contacts between the local elites and the Franks, including ceremonial gift exchanges, had not been established yet. The inflow of Early Carolingian products to Moravia and Slovakia was only incidental. Consequently, based on the source material, it is difficult to reconstruct routes and the chronology of the inflow reliably. However, some of these items were probably imported later, for example together with the second wave of Late Carolingian products that is at the end of the first quarter of the $9^{\text {th }}$ century (Robak 2017-2018). ${ }^{5}$

Furthermore, we can notice that nearly all Early Carolingian types of finds are concentrated in areas of defensive structures or cultural layers of multi-phase hillforts roughly dated back to the second half of the $8^{\text {th }}$ century and the beginning of the $9^{\text {th }}$ century (Tab. 1). In this period, the Middle Danube and

\footnotetext{
4 The chronology of the example from Kraków-Gródek is less certain (Strzyż 2006, fig. 27: 11). In my opinion, a chalice-like prick known from spurs from Menzlin and York (see Kind 2002) disqualifies the spur as an Early Carolingian product. Most likely, the spur should be attributed to the Ottonian times.

5 We can draw similar conclusions about some artefacts found in Southern Poland that could be imported from Bohemia or Moravia (Robak 2018a, 63-68).
} 
Tab. 1. Localities with finds of Avar bronze decorations, hooked spurs and Early Carolinian items.

\begin{tabular}{|c|c|c|c|c|c|}
\hline Site & Site type & $\begin{array}{l}\text { Late Avar } \\
\text { bronze } \\
\text { decorations }\end{array}$ & $\begin{array}{l}\text { Hooked } \\
\text { spurs }\end{array}$ & $\begin{array}{c}\text { Early } \\
\text { Carolingian } \\
\text { items }\end{array}$ & References \\
\hline Bojná-Valy/SK & hill-fort & $\mathrm{x}$ & $\mathrm{x}$ & $\mathrm{x}$ & Robak 2017a \\
\hline Brno-Líšeň/CZ & hill-fort & $\mathrm{x}$ & $x$ & $\mathrm{x}$ & Profantová 2010; 2015; 2016b; Robak 2017a \\
\hline Češov/CZ & hill-fort & - & $x$ & $\mathrm{x}$ & Profantová 2012; 2015 \\
\hline Mikulčice-Valy/CZ & lowland stronghold, graveyard & $\mathrm{x}$ & $\mathrm{x}$ & $x$ & Profantová 2010; 2016b; Robak 2017a \\
\hline Mořinka/CZ & hill-fort & $x$ & $x$ & $x$ & Profantová 2015; 2016a; 2016b; 2017a \\
\hline Olomouc-Povel/CZ & fortified settlement & $x$ & $x$ & $x$ & Profantová 2010; 2016b; Robak 2017a \\
\hline Praha-Kosoř/CZ & hill-fort & $\mathrm{x}$ & - & $x$ & Profantová 2015; 2016a; 2017 \\
\hline Rubín-Dolánky/CZ & hill-fort & $x$ & $x$ & $x$ & Profantová 2010; 2016a; 2016b \\
\hline Smolenice/SK & hill-fort & $\mathrm{x}$ & $\mathrm{x}$ & $x$ & Dušek 1984; Turčan 1994; 1995 \\
\hline Sv. Jan pod Skalou/CZ & hill-fort & $x$ & $x$ & $\mathrm{x}$ & Profantová 2015; 2016a; 2016b; 2017 \\
\hline Tismice/CZ & hill-fort & $x$ & $x$ & $x$ & Profantová 2010; 2015; 2016a; 2016b; 2017 \\
\hline
\end{tabular}

in the Upper Elbe region experienced radical political changes caused by the expansion of the Frankish State and the decline of the Avars. The political changes initiated cultural revolution (expansion of Christianity, changes of the burial rite) and social transformations related to the emergences of the elites. The process, most likely, had started earlier, however, the new geopolitical situation accelerated it. The process resulted in establishing numerous hillforts located in Bohemia, Moravia and Slovakia. Most of these hillforts lost their significance of even perished in the first decades of the $9^{\text {th }}$ century ${ }^{6}$. However, some of the hillforts became cornerstones of future political centres of Great Moravia and Přemyslid's Bohemia. The emergence and emancipation of the Slavic elites are reflected in the archaeological sources. The material includes hooked and quasi-loop spurs (including also specimens made of bronze), Late Avar bronze decorations and many other pieces of weaponry - found at the defensive structures - dated back to the turn of the second half of the $8^{\text {th }}$ century and the beginning of the $9^{\text {th }}$ century (Galuška 2013, 13-97; 2017, 80-92; Profantová 2016a; 2016b; Šalkovský 2015, 102). The presence - though occasional - of Early Carolingian finds is another manifestation of this phenomenon. The hillfort in Smolenice can be linked with the group (horizon) of hillforts with hooked spurs and Late Avar bronzes used at the turn of the $8^{\text {th }}$ and the $9^{\text {th }}$ century.

The distribution of Early Carolingian finds in Central Europe reflects the situation described by historical sources about the Carpathian Basin at the end of the $8^{\text {th }}$ century and the beginning of the $9^{\text {th }}$ century. It seems that the lands located to the north of the Danube, in the Moravia and Vah valleys, did not arouse Frankish interests. Apart from one campaign in the area of the Kamp River, in 791, the Carolingian army was not active on the northern Danube bank. Moravia and lands located further to the north were not a war scene then (Třeštík 2001, 58-62). Due to the strategic importance of Pannonia, military operations during the Frankish-Avar war (791-803) concentrated in that region. Consequently, the Franks, who needed a "buffer zone" protecting the eastern border of the state, suddenly became interested in tribal lands surrounding the empire. The crisis and the fall of the Avars opened a gap between the Sorbian (Lusatian) tribes, subordinated in 782, and Pannonia inhabited by the Avars and the Slavs and quite unexpectedly obtained by the Carolingians in 803. The two campaigns in 805 and 806 to the lands inhabited by Czech tribes and the settlement of the Avars "between Carnuntum and Savaria" have brought changes beneficial to the Franks.

Ordinatio Imperii (817) mentions several such buffer lands governed by Louis the German, including lands inhabited by the Caranthians, the Czechs as well as the Avars and the Slavs living to the east of the Bavarians - this comment, most likely, referred to the Slavs inhabiting the future Eastern March (Třšstík 2001, 103). Consequently, the tribes living in the Moravia valley, not to mention

6 These are localities where so-called Great Moravian Phase or (in other periodization system) Middle Hillfort Period (e.g., Prievidza-Hradec, Klátova Nová Ves, Olomouc-Povel) were not observed. 


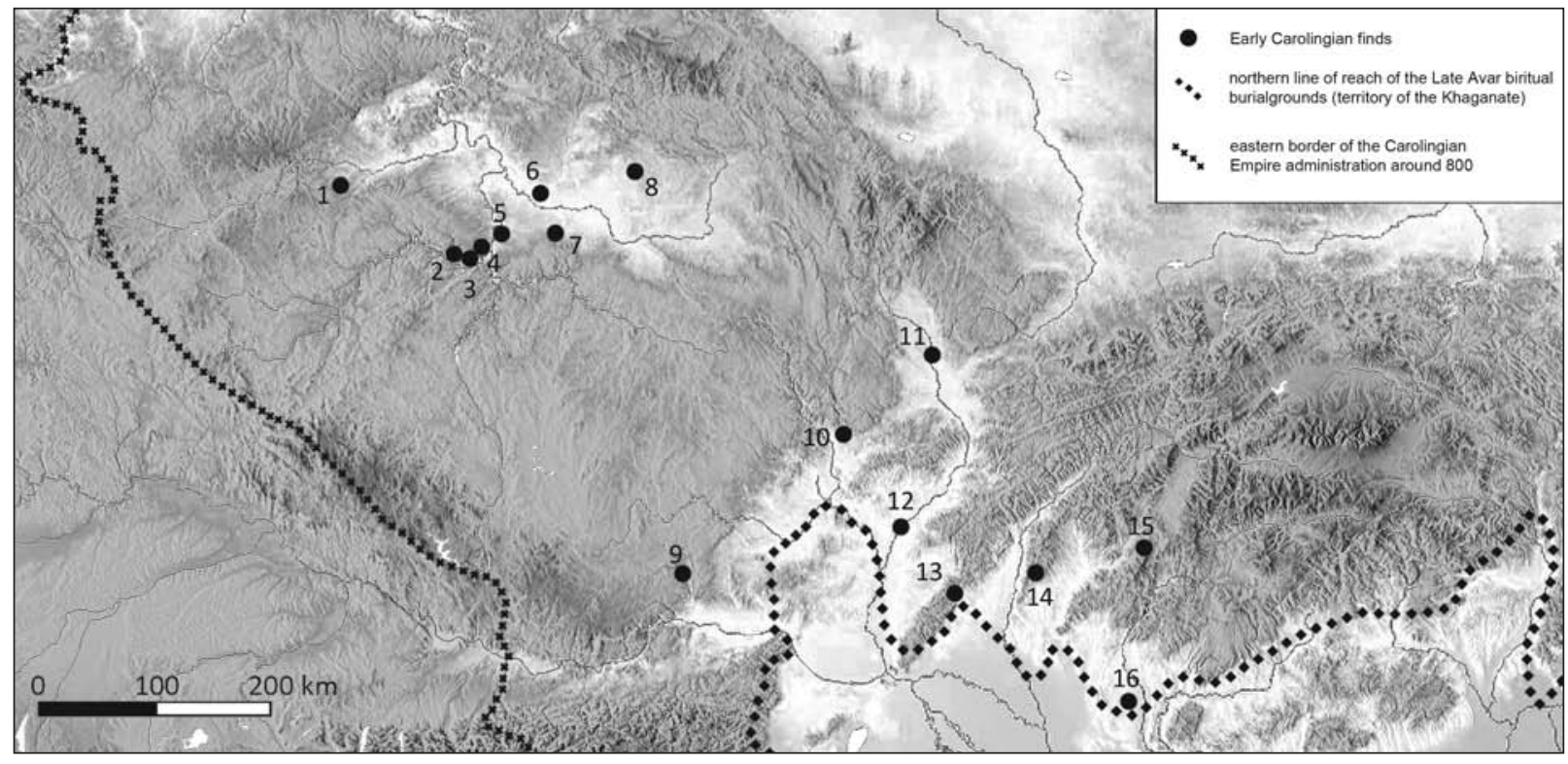

Fig. 6. Early Carolingian finds from the Bohemia, Moravia and Western Slovakia. 1 - Rubin-Dolánky, okr. Louny/CZ (2 small strap ends); 2 - Sv. Jan pod Skalou, okr. Beroun/CZ (small strap end); 3 - Mořinka, ok. Beroun/CZ (strap slide); 4 - Praha-Kosoř, okr. Praha-západ/CZ (small strap end); 5 - Praha-Kunratický les, city of Prague/CZ (belt fitting); 6 - Skorkov, okr. Mladá Boleslav/CZ (spur); 7 - Tismice, okr. Kolín/CZ (strap slide); 8 - Češov, okr. Jičín/CZ (small strap end); 9 - Gars-Thunau, Bez. Horn/AT (buckle in a younger context); 10 - Brno-Líšeň - Staré Zámky, okr. Brno-město/CZ (2 strap ends); 11 - Olomouc-Povel, okr. Olomouc/CZ (small strap end); 12 - Mikulčice-Valy, okr. Hodonín/CZ (3 small strap ends); 13 - Smolenice, okr. Trnava/SK (spur); 14 - Bojná-Valy, okr. Topolčany/SK (small strap end); 15 - Prievidza-Hradec, okr. Prievidza/SK (belt fitting); 16 - Zeliezovce-Kostolná, okr, Levice/SK (small strap end).

those inhabiting territories of today Slovakia, were still outside the buffer zone. The document does not mention these lands. For the first time, the Moravians, or rather their representatives on the Frankfurt Council, appear in the written sources in 822. First diplomatic relations were established, thus, before that date. Probably the process was catalysed by the emergence of a strong power centre in Bavaria (starting from 817) and parallel events in Slavonia and Croatia (the revolt of Ljudevit Posavski in 818-822) that inclined the Bavarian nobility to take a closer look at their neighbours (Třšstík 2001, 101-103), they knew that also other tribes could undertake similar attempts to obtain independence.

It was probably then that the Moravians entered the orbit of direct interests and influences of the Carolingian State. Since that time we can expect the presence of the Slavic Moravian elites in the Carolingian public life and consequently also in the ceremonial exchange of goods and gifts. The situation is well reflected in archaeological sources. Around the turn of the first and the second quarter of the $9^{\text {th }}$ century, we observe a clear wave of Carolingian imports to Moravia - Late Carolingian products dated back to the beginning and the first quarter of the $9^{\text {th }}$ century. Of course, the wave is legible also in Bohemia, which remained in the orbit of Carolingian influences at least since the beginning of the century (Robak 2017-2018).

\section{CONCLUSION}

The spur from Smolenice complements the archaeological panorama of Carolingian finds in the Middle Danube Basin. Paradoxically, this find does not invalidate previous observations (Robak 2013, 191, 192; 2015, 325) that in today Moravia and Slovakia there are no archaeological assemblages containing sets of Early Carolingian weaponry. The collection of such finds includes, apart from the spur, few loose finds of strap fittings from settlement layers and one grave find ${ }^{7}$ (Fig. 6; Robak 2017a; 2018b).

\footnotetext{
7 Mikulčice, grave 108/II. Additionally, grave 129 from Gars-Thunau contained a D-shaped slide decorated with thickenings -
} most likely Early Carolingian. However, the remaining pieces of burial equipment - a Y-type sword and a plate spur with 
Therefore, it would be rather difficult to call the phenomenon a horizon of Early Carolingian finds in this area. Particularly if we compare the situation with the Bohemian Basin where (i) the number of known finds increased significantly in recent years, (ii) variability of types is greater, (iii) finds concentrated in a relatively small area and we can notice a clear cluster around Prague. If we add items made in the Late Carolingian type, but stylistically dated back to the beginning of the $9^{\text {th }}$ century, the concentration would be even greater (see Robak 2018b, fig. 8). Not to mention the situation in Slovenia or Croatia where the horizon of Early Carolingian finds is legible - also in archaeological assemblages - and the forms of finds are more varied (Bilogrivić 2019; Jurčević 2011; Karo 2012; Milošević 2012; Petrinec 2009).

Translated by Magdalena Adamus

\section{LITERATURE}

Bilogrivić 2019

Brather 1996

Deubler 1966

Dušek 1965

Dušek 1979

Dušek 1984

Dušek/Dušek 1984

Dušek/Dušek 1995

Dzino 2010

Eisner 1935

Farkaš 1995

Galuška 2013

Galuška 2017

Goßler/Posluschny 1998

Janowski 2017

Jurčević 2011

Karo 2012

Kind 2002

Kind 2007
G. Bilogrivić: Formiranje identiteta elite u istočno-jadranskome zaleđu na prijelazu sa 8. u 9. stoljeće. Uloga karolinškog oružja. Vjesnik Arheološkog muzeja u Zagrebu 52, 2019, 113-147.

S. Brather: Merowinger- und karolingisches „Fremdgut” bei den Nordwestslawen Gebrauchsgut und Elitenkultur im südwestlichen Ostseeraum. Prähistorische Zeitschrift 71,1996, 46-84.

H. Deubler: Neue karolingerzeitliche Grabfunde bei Sundremda, Kr. Rudolstadt. Ausgabungen und Funde 11, 1966, 277-281.

M. Dušek: Výskum hradiska z mladšej doby halštatskej v Smoleniciach roku 1963. Archeologické rozhledy 17, 1965, 487-495.

S. Dušek: Vel'komoravské pohrebisko v Smoleniciach. Slovenská archeológia 27, 1979, 365-374.

S. Dušek: Ostroha s háčikmi zo Smoleníc. In: E. Studeníková/E. Zachar (ed.): Zborník prác L’udmile Kraskovskej (k životnému jubileu). Bratislava 1984, 159-161.

M. Dušek/S. Dušek: Smolenice-Molpír. Befestigter Fürstensitz der Hallstattzeit I. Nitra 1984.

M. Dušek/S. Dušek: Smolenice-Molpír. Befestigter Fürstensitz der Hallstattzeit II. Nitra 1995.

D. Dzino: Becoming Slav, Becoming Croat. Identitiy Transformation in Post-Roman and Early Medieval Dalmatia. Leiden - Boston 2010.

J. Eisner: Prehistorický výzkum na Slovensku a v Podkarpatské Rusi v roku 1934. Sborník Muzeálnej slovenskej spoločnosti 29, 1935, 51-80.

Z. Farkaš: Slovanské pohrebisko v Smoleniciach. AVANS 1994, 1995, 50, 51.

L. Galuška: Hledaní původu. Od avarských bronzů ke zlatu Velké Moravy. Brno 2013.

L. Galuška: Slované - stopy předku․ O Moravě v 6.-10. století. Brno 2017.

N. Goßler/A. Posluschny: Zu einem frühkarolingischen Sporn aus der Siedlung von Runkel-Ennerich, Kr. Limburg-Weilburg. Germania 76, 1998, 885-895.

A. Janowski: Chronology and evolution of Early Medieval hooked spurs in the light of new finds and analyses. Fasciculi Archaeologiae Historicae 30, 2017, 181-191.

A. Jurčević: Nalazi ranokarolinškog oružja i konjaničke opreme u doba formiranja Hrvatske Kneževine. Starohrvatska prosvijeta 38, 2011, 111-477.

Š. Karo: Zgodnjekarolinške najdbe s slovenskih najdišč. In: I. Lazar/B. Županek (ur.): EMONA - med Akvilejo in Panonijo. Koper 2012, 447-458.

T. Kind: Archäologische Funde von Teilen der Reiterausrüstung aus Europa und ihr Beitrag zur Kultur- und Sozialgeschichte der Ottonenzeit. In: J. Henning (Hrsg.): Europa im 10. Jahrhundert. Archäologie einer Aufbruchszeit. Mainz 2002, 283-299.

T. Kind: Westliche Einflüsse auf der östlichen Balkanhalbinsel im Spiegel der frühund hochmittelalterlichen Reitausrüstung. In: J. Henning (ed.): Post-Roman Towns. Trade and Settlement in Europe and Byzantium 2. Byzantium, Pliska, and the Balkans. Berlin - New York 2007, 543-612.

a long prick - date the grave back to the end of the $9^{\text {th }}$ century. The radiocarbon analysis confirmed this dating (Nowotny 2013, 446, 448, fig. 3). Therefore, we cannot relate this assemblage to the horizon of Early Carolingian finds. However, it confirms that some types of decorations were used for a relatively long time or even stored as valuable pieces of material. 
Kleemann 2002

Laux 1983

Loubal 1935

Milošević 2006

Milošević 2012

Nagy 1896

Nowotny 2013

Petrinec 2009

Pieta/Ruttkay 2017

Profantová 1994

Profantová 2010

Profantová 2012

Profantová 2015

Profantová 2016a

Profantová $2016 b$

Profantová 2017

Robak 2013

Robak 2015

Robak 2017a

Robak 2017b

Robak 2017-2018

Robak 2018a

Robak $2018 b$
J. Kleemann: Sachsen und Friesen im 8. und 9. Jahrhundert. Eine archäologisch-historische Analyse ihrer Grabfunde. Oldenburg 2002.

F. Laux: Der Reihengräberfriedhof in Oldendorf, Samtgemeinde Amelinghausen, Kr. Lüneburg, Niedersachsen. Ein Beitrag zu den frühgeschichtlichen Gräberfeldern im Bardengau. Hammaburg NF 5, 1983, 91-147.

A. Loubal: Archeologické nálezy v Trnavskom kraji z doby železnej. Slovenský deník 153, 1935, 3.

A. Milošević: Ranokarolinška brončana ostruga iż korita rijeke Centine u Sinjkom polju. Vjesnik za arheologiju i povijest dalmatinsku 99, 2006, 299-307.

A. Milošević: Novi mač iz Koljana u svjetlu kontakata s nordijskim zemljama u ranom srednjem vijeku. Histria Antiqua 21, 2012, 459-470.

G. Nagy: Hadtörténelmi emlékek az ezredéves kiállításon. Archaeologiai Értesitő 16, 1890, 344-365.

E. Nowotny: Repräsentation zwischen Karolingerreich und Großmähren. Das Beispiel des Gräberfeldes von Thunau am Kamp, Obere Holzwiese. In: M. Hardt/ O. Heinrich-Tamáska (Hrsg.): Macht des Goldes, Gold der Macht. Herrschafts- und Jenseitsrepräsentation zwischen Antike und Frühmittelalter im mittleren Donauraum. Akten des 23. Internationalen Symposiums der Grundprobleme der frühgeschichtlichen Entwicklung im mittleren Donauraum, Tengelic, 16.-19. 11. 2011. Weinstadt 2013, 439-459.

M. Petrinec: Gräberfelder aus dem 8. bis 11. Jahrhundert im Gebiet des frühmittelalterlichen kroatischen Staates. Split 2009.

K. Pieta/M. Ruttkay: Zeit des Untergangs. Ein Hort spätawarischer Bronzen aus Dolné Orešany in der Westslowakei. In: B.V. Eriksen et al. (Hrsg.): Interaktion ohne Grenzen. Beispiele archäologischer Forschungen am Beginn des 21. Jahrhunderts. Band I. Schleswig 2017, 541-554.

N. Profantová: K nálezům ostruh z konce 7.-9. stol. v Čechách. In: J. Fedrich/ J. Klapšte/P. Vařeka (eds.): Mediaevalia Archaeologica Bohemica 1993. Památky Archeologické. Supplementum 2. Praha 1994, 60-85.

N. Profantová: Awarische Funde in der Tschechischen Republik: Forschungsstand und neue Erkenntnisse. Acta Archaeologica Carpathica 45, 2010, 203-270.

N. Profantová: Nově získané kovové předměty z hradiště Češov a jeho okoli. Archeologie ve středních Čechách 16, 2012, 315-320.

N. Profantová: The horse harness. spurs and stirrups in Bohemia in $8^{\text {th }}$ and $9^{\text {th }}$ century. In: C. Cosma (ed.): Warriors, weapons and harness from the $5^{\text {th }}-10^{\text {th }}$ centuries in Carpathian Basin. Cluj-Napoca 2015, 281-297.

N. Profantová: Errichtung und Zerstörung der ersten frühmittelalterlichen Burgwälle in Böhmen (8./9. Jahrhundert). In: F. Biernamm/T. Kersting/A. Klammt (Hrsg.): Die frühen Slawen - von der Expansion zu gentes und nationes. Teilband 1. Beiträge zum Schwerpunktthema. Beiträge der Sektion zur slawischen Frühgeschichte des 8. Deutschen Archäologiekongresses in Berlin, 06.-10. Oktober 2014. Langenweissbach 2016, 223-239.

N. Profantová: Ostruhy jako doklady přítomnosti elity v 8. a 9. století v Čechách. Archaeologia Historica 41, 2016, 7-40.

N. Profantová: New data about the earliest of early medieval hill-forts and hillsites in the Central Bohemia ( $8^{\text {th }}$ and first half of $9^{\text {th }}$ century). In: G. Fusek (Hrsg.): Archäologische Studien zum frühen Mittelalter. Nitra 2017, 99-114.

Z. Robak: Studia nad okuciami rzemieni w typie karolińskim I. Nitra 2013.

Z. Robak: Items decorated with the Tassilo Chalice style in the Western Slavic Territories. Slovenská archeológia 63, 2016, 309-340.

Z. Robak: K otázke počiatkov včasnostredovekého osídlenia Bojnej. In: K. Pieta/ Z. Robak (ed.): Bojná 2. Nové výsledky výskumov včasnostredovekých hradísk. 2. Nitra 2017, 53-64.

Z. Robak: Carolingian Decoration from Dolné Orešany. In: G. Fusek (Hrsg.): Archäologische Studien zum frühen Mittelalter. Nitra 2017, 153-160.

Z. Robak: Chronology and periodisation of imports of Carolingian military equipment in the Carpathian Basin between the eight and the tenth centuries. Antaeus Communicationes ex Instituto Archaeologico Academiae Scientiarum Hungaricae 35-36, 2018, 327-344.

Z. Robak: Carolingian or not? An analysis of the fitting from Haliczany in the context of other Early Medieval finds from selected areas of the Western Slavic Territories. Slovenská archeológia 66, 2018, 49-105.

Z. Robak: Two Carolingian strap-ends on exhibition in Želiezovce (okr. Levice). Archäologisches Korrespondenzblatt 48, 2018, 417-435. 
Romsauer 2011

Rötting 1999

Ruttkay 1975

Sander 2007

Sándorfy 1890

Schlüter/Zehm 1992

Schulze-Dörrlamm 2010

Stein 1967

Strzyż 2006

Šalkovský 2015

Šimčík 2007

Štih 2010

Třeštík 2001

Turčan 1994

Turčan 1995

Turčan 2011

Wachowski 1991

Wamers 1993

Wamers 1994

Wamers 1999

Żak 1959
P. Romasauer: Smolenice predhistorické. In: K. Novákova (ed.): Smolenice. Vlastivedná monografia obce. Smolenice 2011, 39-63.

H. Rötting: Zu Bestattung und Repräsentation im friesischen und fränkischen Stil im Spiegel herausgehobener Grabanlangen von Schortens, Ldkr. Friesland. In: F. Both/H. Aouni (Hrsg.): Über allen Fronten. Nordwestdeutschland zwischen Augustus und Karl dem Großen. Oldenburg 1999, 231-248.

A. Ruttkay: Waffen und Reiterausrüstung des 9. bis zur ersten Hälfte des 14. Jahrhunderts in der Slowakei (I). Slovenská archeológia 23, 1975, 119-216.

U. Sander: Der ältere Lindauer Buchdeckel in seinen originalen Bestandteilen. Bonn 2007.

N. Sándorfy: A szomolányi őstelepről. Archaeologiai Értesitő 10, 1890, 66-71.

W. Schlüter/B. Zehm: Osnabrück-Innerstadt, FStNr. 10. Archäologische Mitteilungen Nordwestdeutschland 15, 1992, 316, 318.

M. Schulze-Dörrlamm: Gräber mit Münzbeigabe im Karolingerreich. Jahrbuch des Römisch-Germanischen Zentralmuseums 57, 2010, 339-388.

F. Stein: Adelsgräber des achten Jahrhunderts in Deutschland. Berlin 1967.

P. Strzyż: Uzbrojenie we wczesnośredniowiecznej Małopolsce. Łódź 2006.

P. Šalkovský: Hrady západných Slovanov. Nitra 2015.

P. Šimčík: Fragmenty krúžkovej zbroje z lokalít Smolenice-Molpír a Dolné Orešany - poloha Železník. Zborník SNM 101. Archeológia 17, 2007, 175-188.

P. Štih: The Middle Ages between the Eastern Alps and the Northern Adriatic. Leiden Boston 2010

D. Třeštík: Vznik Velké Moravy. Moravané, Čechové a střední Evropa v letech 791-871. Praha 2001.

V. Turčan: Ďalšie slovanské nálezy zo Smoleníc-Molpíra. Zborník SNM 88. Archeológia 4, 1994, 75-84.

V. Turčan: Nové nálezy ostrôh zo Smoleníc-Molpíra. Zborník SNM 89. Archeológia 5, 1995, 77-82.

V. Turčan: Karolínsky meč zo Smoleníc. In: V. Turčan (ed.): Karolínska kultúra a Slovensko. Zborník SNM. Archeológia. Supplementum 4. Bratislava 2011, 71-104.

K. Wachowski: Oddziaływania zachodnie na wytwórczość ostróg haczykowatych u Słowian. Przeglad Archeologiczny 38, 1991, 85-107.

E. Wamers: Insular Art in Carolingian Europe: The Reception of Old Ideas in a New Empire. In: R. M. Spearman/J. Higgitt (eds.): The Age of Migrating Ideas. Early Medieval Art in Northern Britain and Ireland. Edinburgh 1993, 35-44.

E. Wamers: Die frühmittelalterlichen Lesefunde aus der Löhrstraße (Baustelle Hilton II) in Mainz. Mainz 1994.

E. Wamers: Insulare Kunst im Reich Karls des Großen. In: Ch. Stiegemann/ M. Wemhoff (Hrsg.): 799 - Kunst und Kultur der Karolingerzeit. Karl der Große und Papst Leo III. in Paderborn 3. Beiträge zum Katalog der Ausstellung Paderborn 1999. Handbuch zur Geschichte der Karolingerzeit. Mainz 1999, 452-464.

J. Żak: Najstarsze ostrogi zachodniosłowiańskie. Warszawa - Wrocław 1959.

\title{
Včasnokarolínska ostroha zo Smoleníc, nález z roku 1934
}

\author{
Zbigniew Robak
}

Súhrn

Ostroha z hradiska Molpír v Smoleniciach (obr. 1; 2) je nález, ktorý je v literatúre známy takmer sto rokov. Pochádza z výskumu A. Loubala z roku 1934 v blízkosti „druhého valu“ (podla zamerania Š. Janšáka z roku 1930). Prvýkrát sa o nej zmienil A. Loubal (1935), pričom ju správne opísal ako „karolínsku“, čo zopakoval J. Eisner (1935, 78). Dokumentácia z prieskumu A. Loubala sa dodnes nezachovala, takže je t’ažké povedat’ niečo bližšie o okolnostiach nálezu. Informácia o tom, že sa ostroha našla "medzi halštatskou a slovanskou keramikou z 9.-10. stor." (Loubal 1935) naznačuje, že sa nachádzala skôr v kultúrnej vrstve ako vo výplni objektu. Kresba ostrohy v katalógu múzea bola zverejnená až v roku 1975, a to spolu s informáciami o tom, že predmet bol stratený (Ruttkay 1975, 177, 178, obr. 
22: 9). Našiel sa však pod iným číslom. Kresba v katalógu múzea je vel’mi odlišná od originálu. Na základe publikácie z roku 1975 (Ruttkay 1975, obr. 22: 9) by sa dalo uvažovat’ o tom, že išlo o pomerne jednoduchý kus včasnostredovekej očkovej alebo tzv. očkovej ostrohy.

Ostroha má dížku 12,2 cm. Jedno z očiek je poškodené a oblúk nad ním mierne ohnutý. Predmet je zachovalý a je vo vel'mi dobrom stave. Ostroha bola vyhotovená z dvoch častí, a to z oblúka a bodca, ktorý bol následne zapustený do otvoru s priemerom 0,6 cm. Rozpätie ramien je 8,7 cm, vnútorná výška oblúku 9,5 cm. Bol vyrobený z tyčinky trojuholníkového prierezu. Na koncoch ramien sú očká, ktoré umožňujú prevlečenie remeňa maximálnej šírky $1,2 \mathrm{~cm}$ a hrúbky $2 \mathrm{~mm}$. Očká boli vyrobené ohnutím splošteného konca tyčinky dovnútra, hoci miesto spojenia je viditelné iba pri velmi podrobnom skúmaní. Na vonkajšom okraji očiek sú dve zhrubnutia v tvare kolienok. Výška kónického bodca je $2 \mathrm{~cm}$ a jeho celková dĺžka spolu s častou zapustenou do rámu 2,7 cm. Bodec je profilovaný.

Smolenická ostroha je typickým príkladom včasnokarolínskej očkovej ostrohy (nemecky Schlaufensporen), t. j. takej, v ktorej boli konce ramien formované do pravouhlého alebo oválneho, menej často trojuholníkového rámu. Podobné exempláre sú známe najmä z oblastí dnešného severného Nemecka (Goßler/Posluschny 1998; Kind 2007, 586, 587) a vyskytujú sa aj v Dalmácii spolu s d’alšími importami zo západu (Milošević 2006). Exemplár zo Smoleníc možno datovat na prelom 8. a 9. stor. alebo na začiatok 9. stor. Jeho podobnost’ s nálezmi zo Sundremdy (Deubler 1966, tab. 39), Osnabrücku (Schlüter/Zehm 1992, obr. 31: 4) a Gornji Vrbljani (Milošević 2006, obr. 6: 1) potvrdzuje domnienku, že ide o import zo západnej Európy.

Smolenická ostroha doplňa archeologickú panorámu karolínskych nálezov v strednom Podunajsku. Paradoxne popiera predchádzajúce názory (Robak 2013, 191, 192; 2015, 325), že v oblasti dnešnej Moravy a Slovenska chýbajú archeologické celky obsahujúce súbory včasnokarolínskych militárií. Zbierka pozostáva z niekol’kých ojedinelých nálezov, okrem ostrohy, aj nákončia, pochádzajúcich zo sídliskových vrstiev a z jedného hrobu (obr. 6; Robak 2017a; 2018b). Preto je t’ažké hovorit’ o horizonte včasnokarolínskych nálezov v týchto oblastiach, najmä ked’ porovnáme stav archeologických prameňov, napr. s rýchlo sa meniacim stavom zdrojov z oblasti Českej kotliny, kde (i) je ich nárast v posledných rokoch významný, (ii) počet typov väčší, (iii) a vyskytujú sa hlavne na menšom území v okolí Prahy (ak prirátame aj tie, ktoré patria do neskorokarolínskeho typu, s datovaním na začiatok 9. stor., hustota by bola väčšia, pozri Robak 2018b, obr. 8). Nehovoríme o porovnaní s oblastami Slovinska alebo Chorvátska, kde je horizont včasnokarolínskych nálezov jasne čitatelný a vyznačuje sa rôznymi formami a ich prítomnostou v archeologických celkoch (Bilogrivić 2019; Jurčević 2011; Karo 2012; Milošević 2012; Petrinec 2009).

Obr. 1. Smolenice-Molpír. Očková ostroha. Železo. Kresba N. Vaššová, foto Z. Robak.

Obr. 2. Smolenice-Molpír. Očková ostroha. Železo (súkromná zbierka). Foto SNM - Archeologické múzeum. Bez mierky. Obr. 3. Smolenice-Molpír. 1, 2 - hlavice karolínskych mečov; 3 - fragment prackovej ostrohy. Železo (Dušek/Dušek 1984; 1995).

Obr. 4. Smolenice-Záruby. Karolínsky meč typu H. Železo (Turčan 2011).

Obr. 5. Správy zo Slovenského denníka z 5. júla 1935.

Obr. 6. Včasnokarolínske nálezy z Čiech, Moravy a západného Slovenska. 1 - Rubin-Dolánky, okr. Louny/CZ (dve malé nákončia); 2 - Sv. Jan pod Skalou, okr. Beroun/CZ (malé nákončie); 3 - Mořinka, ok. Beroun/CZ (prevliečka); 4 - Praha-Kosoř, okr. Praha-západ/CZ (malé nákončie); 5 - Praha-Kunratický les, city of Prague/CZ (opaskové kovanie); 6 - Skorkov, okr. Mladá Boleslav/CZ (ostroha); 7 - Tismice, okr. Kolín/CZ (prevliečka); 8 - Češov, okr. Jičín/ CZ (malé nákončie); 9 - Gars-Thunau, Bez. Horn/AT (pracka v mladšom kontexte); 10 - Brno-Líšeň - Staré Zámky, okr. Brno-město/CZ (dve malé nákončia); 11 - Olomouc-Povel, okr. Olomouc/CZ (malé nákončie); 12 - Mikulčice-Valy, okr. Hodonín/CZ (tri malé nákončia); 13 - Smolenice, okr. Trnava/SK (ostroha); 14 - Bojná-Valy, okr. Topolčany/SK (malé nákončie); 15 - Prievidza-Hradec, okr. Prievidza/SK (opaskové kovanie); 16 - Želiezovce-Kostolná, okr, Levice/SK (malé nákončie).

Tabela 1. Lokality s nálezmi avarských bronzových ozdôb, háčkových ostrôh a včasnokarolínskych predmetov.

Mgr. Zbigniew Robak, PhD.

Archeologický ústav SAV

Akademická 2

SK - 94921 Nitra

zbigniew.robak@savba.sk 